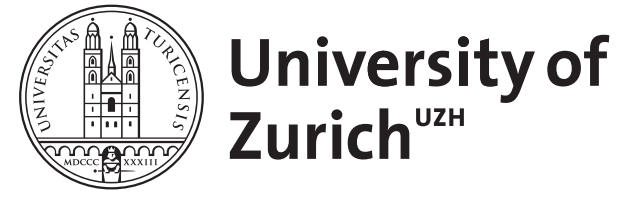

\title{
Preventing hypoxia
}

Zilberman, Paul Norbert ; Biro, Peter

DOI: https://doi.org/10.1097/EJA.0000000000000406

Posted at the Zurich Open Repository and Archive, University of Zurich ZORA URL: https://doi.org/10.5167/uzh-118032

Journal Article

Published Version

Originally published at:

Zilberman, Paul Norbert; Biro, Peter (2016). Preventing hypoxia. European Journal of Anaesthesiology, 33(4):303-305.

DOI: https://doi.org/10.1097/EJA.0000000000000406 


\section{CORRESPONDENCE}

\section{Preventing hypoxia}

Paul Norbert Zilberman and Peter Biro

From the Hadassah Mount Scopus University Hospital, Kiriat Hadassah, Jerusalem, Israel (PNZ); and Institute of Anaesthesiology, University Hospital, Zurich, Switzerland (PB)

Correspondence to Paul Norbert Zilberman, Staff Anaesthetist, Hadassah Mount Scopus University Hospital, Kiriat Hadassah, Jerusalem, Israel

Tel +972 526838779; Fax +972 25385486;

e-mail: paulzi60@yahoo.com

Editor,

We read with interest the recently published Editorial ' $\mathrm{O}_{2}$, anybody', by Hendricks and colleagues ${ }^{1}$ and we would like to make a few comments.

Preventing hypoxia is basic knowledge that all anaesthesia residents are extensively taught. The paradox is that the more sophisticated anaesthesia machines become, the more the clinician may be lulled into a false sense of security. Another difficulty stems from the diversity of anaesthesia machines, types of hypoxia preventing devices, monitors etc., as mentioned in the Editorial by Hendricks et al. ${ }^{1}$ Preventing hypoxia is a complex but logical process. Once one adapts oxygen flow to the particular patient's conditions such as age, weight, comorbidities and surgery, different levels of surgical stimulation, the whole process of delivering the necessary flow of oxygen, becomes easy to understand. This letter intends to provide the clinician with a very simple tool to stay on the safe side, no matter what type of anaesthesia machine is used.

It all starts with the basal metabolic requirements. Since the works of Samuel Brody, ${ }^{2}$ it has been accepted that in a normal adult person at rest the metabolic oxygen requirement is $3.5 \mathrm{ml} \mathrm{kg}^{-1} \mathrm{~min}^{-1}{ }^{1}$ Under general anaesthesia, this requirement drops by 10 to $25 \%$. $^{3}$ Thus, for a $70 \mathrm{~kg}$ person, the basal oxygen requirement is

$70 \times 3.5=245 \mathrm{ml} \mathrm{min}{ }^{-1}$

For the sake of simplicity, this can be rounded to $250 \mathrm{ml} \mathrm{min}^{-1}$. To eliminate the eventuality of hypoxia even further it is better to avoid $\mathrm{N}_{2} \mathrm{O}$. We propose to mix this $250 \mathrm{ml}$ of oxygen with the same amount of air. This results in a total flow of $500 \mathrm{ml} \mathrm{min}^{-1}$, which contains additionally another $52.5 \mathrm{ml}$ oxygen $\mathrm{min}^{-1}$ $\left(250 \mathrm{ml} \mathrm{min}^{-1} \times 0.21 \%\right):$

$250+52.5=302.5 \mathrm{ml}$ oxygen $\mathrm{min}^{-1}$

At the fresh gas flow outlet, this leads to a $\mathrm{FiO}_{2}(1+0.2) /$ $2=0.6$

We must also consider the leaks from the machine and the conformation of the circuit. Older anaesthesia machines have leaks of around $150 \mathrm{ml} \mathrm{min}^{-1}$. These can be indicated automatically by the machine and, if desired for didactical purposes, by the user. ${ }^{4,5}$ Modern anaesthesia machines usually have fewer leaks. However, not everywhere in the world has such machines. So, let us add to our calculation $75 \mathrm{ml} \mathrm{min}^{-1}$ of oxygen and $75 \mathrm{ml} \mathrm{min}^{-1}$ of air, to keep the $\mathrm{FiO}_{2}$ in the fresh gas flow constant at 0.6. This results in a total gas flow of $500+150=650 \mathrm{ml} \mathrm{min}^{-1}$ and a total oxygen flow of $302.5+75+(0.21 \times 75)=302.5+75+15.75=393.25 \mathrm{~m}-$ $393.25 \mathrm{ml} \mathrm{min}^{-1}$.

The gas analyser draws $150 \mathrm{ml} \mathrm{min}^{-1}$ through the sample line. Newer devices (PHASEIN: www.masimo.com/ oem/capnography.htm) extract less (approximately $50 \mathrm{ml} \mathrm{min}^{-1}$ ) but many gas analysers still use the older models. If the diverted gas is scavenged and discarded to the atmosphere, another $150 \mathrm{ml}$ must be added in a similar way as it was calculated for the leaks. Therefore, $75 \mathrm{ml}$ oxygen $+75 \mathrm{ml}$ air must be added:

$650+150=800 \mathrm{ml} \mathrm{FGF}(400 \mathrm{ml}$ oxygen

$$
+400 \mathrm{ml} \text { air) }
$$

with a resulting oxygen flow of

$393.25+75+(0.21 \times 75)=484 \mathrm{ml} \mathrm{min}^{-1}$

It has to be mentioned that adding this flow to compensate for the gas analyser extraction is just another safety precaution, bringing even more oxygen to the circuit and preventing eventual volume deficits. If the gas analyser exhaust is returned to the breathing circuit at the expiratory limb to allow for $\mathrm{CO}_{2}$ absorption, this $150 \mathrm{ml}$ need not be added.

Obviously, this simple calculation offers a large margin of safety except in very high metabolic states such as 
malignant hyperthermia. In fact, the circuit provides practically twice the necessary amount of oxygen. However, the oxygen concentration in the fresh gas flow is not what reaches the patient due to mixing with gases returned from the expiratory limb. The lower the fresh gas flow, the higher the percentage of rebreathed gases. However, under these assumptions a hypoxic mixture is practically excluded.

As these calculations may show, even with older anaesthesia machines a safe and logical reductions in fresh gas flow is possible. The calculations may pose some practical problems because the flow meters must be eye 'tuned', which is not a very exact method. However, the basic elements presented above provide safe and simple tools to reduce flows to levels close to what is really needed, thus avoiding unnecessary waste and pollution. Extensive literature on low flow anaesthesia is also available.

An important issue must be mentioned: all these calculations are for the maintenance phase, after the patient's tissue gas tensions have been equilibrated with the circuit and the clinician now needs to estimate the correct fresh gas flows to deliver sufficient oxygen and anaesthetic agent to the patient. Furthermore, by application of a simple formula using the settings for fresh gas flow and the resulting $\mathrm{FiO}_{2}$, the actual oxygen uptake can be calculated during steady-state conditions with a fair level of precision, which, in turn, may be used to adjust the settings accordingly. ${ }^{6}$
There is no such a thing as a perfect fail-safe device. The last line of defence is the educated user with a sound understanding of the principles of low flow ventilation and the technical features and limitations of the anaesthesia machine used. Combining the desired level of clinician attention with a reliable gas analysers is the key to keep the patient well inside the 'safety zone'.

\section{Acknowledgements related to this article}

Assistance with the letter: none.

Financial support: none.

Conflicts of interest: none.

\section{References}

1 Hendricks JFA, De Wolf AM, De Hert S. $\mathrm{O}_{2}$, anybody? Eur J Anaesthesiol $2015 ; 32: 371-373$.

2 Brody S. Bioenergetics and growth. Baltimore, MD: Reinhold Publishing Corporation, Waverly Press; 1945.

3 Morgan GE, Mikhail MS. Chapter 7: clinical anesthesiology.Inhalational anesthetics, 2nd ed. 1996, pp. 124-125.

4 Baum AJ. Chapter 3: low flow anaesthesia - the theory and practice of low flow, minimal flow and closed system anesthesia.Pharmacokinetics of anaesthetic gases, 2nd ed. Butterworth - Heinemann; 2001. pp. 39-39.

5 Baum AJ. Chapter 10: low flow anaesthesia - the theory and practice of low flow, minimal flow and closed system anesthesia. Low flow in clinical practice, 2nd ed. Butterworth - Heinemann; 2001. pp. 221-222.

6 Biro P. A formula to calculate oxygen uptake during low flow anesthesia based on $\mathrm{FIO}_{2}$ measurement. J Clin Monit Comput 1998; 14:141-144. 